\title{
終戰前後に於ける人造石油事業に就て
}

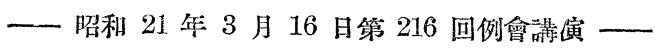

\section{榎本隆一 郎}

\section{[I]、今次大戰開戰以來の人造石油等産實蹟}

今次大戰勃發時の昭和 16 年度より終戰時の昭和 20 年度迄の 5 年間の年次別人造石油の生 產狀況は日䓣統計飞て，昭和 16 年度 $194,142 \mathrm{kl}, 17$ 年度 $240,414 \mathrm{kl}, 18$ 年度 $272,290 \mathrm{kl}, 19$ 年度 $215,583 \mathrm{kl} ， 20$ 年度 $45,894 \mathrm{kl}$ となつて居る。郎ち開戰後照增を續り，18 年度て於て頂 敤に達し 19 年度に於て若干の减産を示し, 終戰年度に於ては極度に减產を示した。尤もとの 20 年度 $45,894 \mathrm{kI}$ 亡云心數字の中には，終戰時より連絡杜絶せる外地關係の生產は揭記され て居らす，且つ內地に於て必終戰後兩三ヶ月間は，瀧川，日產，三他の三工場に於て若千の生

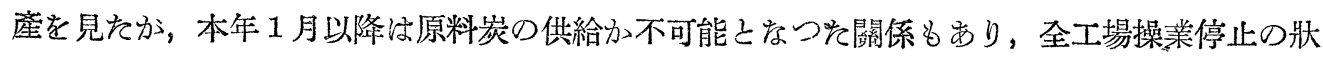
况に立到つて現在に及んて居る。

以上の生產量を內容的に見るを，先づ品種別に付生產の頂上に達した昭和 18 年度に例を取 つて見ると，航空揮發油 $361 \mathrm{kl}(01 \%)$ ，普通揮發油 $32,352 \mathrm{kl}$ (119\%)，輕伷 $26,662 \mathrm{kl}$ (9.8 \%)，一號重㹨 $158,518 \mathrm{kl}(583 \%)$ ，二號重油 48,399kl（17.7\%)，閏骬伷（てれは主としてゴ ム閏滑油で） $5,998 \mathrm{kl}(22 \%)$ とをつて居る。郎ち重伷方製品の $76 \%$ を占的，大戰中最も要 請せられ，刃人石部門としても夙に自ら自負して居え航空揮發伷及撋滑油は，終戰迄装置末整

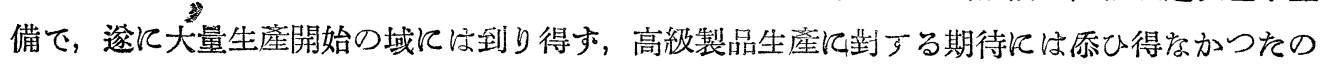
である。

而加上上記總額 $272,290 \mathrm{kl}$ の中，撫順の頁岩㣙に約 16 萬 $\mathrm{kl}$ ，郎占約 $60 \%$ 占めて居り， 爾餘の人造石油製品は，大約 11 萬 $\mathrm{kl}$ に過きなかつたのでる。次，各工場としてその生

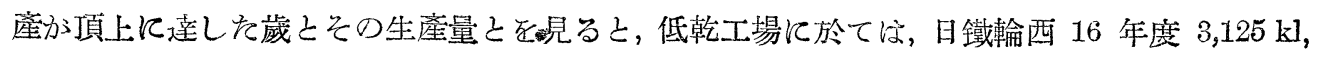
東京瓦斯化學 17 年度 $786 \mathrm{kl}$ ，日本油化 18 年度 $4,701 \mathrm{kl}$ 東邦化學 17 年度 $1,399 \mathrm{kl}$ ，宇部與 產 17 年度 $11,852 \mathrm{kl}$ ，帝然宇部 18 年度 $19,249 \mathrm{kl}$, 日產若松 19 年度 $21,569 \mathrm{kl}$, 帝然內淵 19 年度 $16,767 \mathrm{kl}$, 帝燃內幌 18 年度 $17,926 \mathrm{kl}$, 日䇪永安 17 年度 $4,624 \mathrm{kl}$, 朝㙰人石阿吾 地 15 年度 $12,229 \mathrm{kl}$ （これには若干水添油をも含む）等で，低乾全體こしては，19 年度 95,360 $\mathrm{kl}$ 少最大であつた。合成工場沉於ては，日人石龍川 19 年度 $6,606 \mathrm{kl}$ ，尼人 18 年度 $200 \mathrm{kl}$, 三他 18 年度 $13,872 \mathrm{kl}$ ，合成全體としては，19 年度 $17,806 \mathrm{kl}$ 名最大であつた。

又頁岩油注，17，18 年度何れ多約 16 萬 $\mathrm{kl}$ を出したのか;最大ですり，水添は東邦，日本 油化の兩社に於て，天然石伷系の水添航空揮發油を相富量生產して居るか，人石本來の製品た る石若系水添伷は，阿吾地及擐順共に長期の試遭轉に終始し，其の生產量な殆んと揭記するに 足りない程度に終つそのである。 
ヌゴム潤愲油は，19 年度 $23,284 \mathrm{kl}$ を出して居る。以上の生產實蹟を 通觀し 感ぜられると とは，昭和 12 年度人造石㣙振與計畫として 7 年後の昭和 18 年度飞 200 萬 $\mathrm{kl}$ 生產實現を 目標として發足せられ，更に昭和 15 年に到つて 400 萬 $\mathrm{kl}$ 案が强化策定せられねのであつた

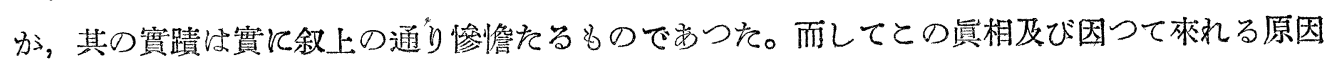
を深く堀り下けて檢討すると，本事業は，支那事變續いて今令炏の戰争と云ふ國力不相應の外戰 裡に於て建設せられ，國家としての過重負擔か全期間を通して斯業推進の凡有る部面に影響を

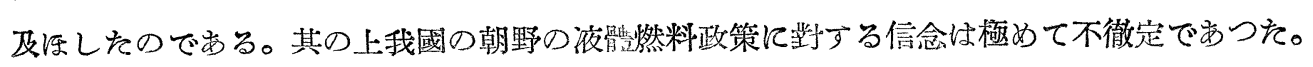
此の如き客觀的壯勢に加へて，本事業に關聯せる我國の科學技術の水隼が，今日より振り返つ て見ると，如何にも低位に有つそ。とれ等各種の事項方，因果相關的に影響して，かかる結果 を招來したとと己思はれるのでのるが，との事て就て之を徹底的に究め，以て今後の考證に資 するととは，人造石油事業に關係を有した吾々の重大空る責任であると考へられる。

\section{[II] 戰爭末期に入リ生座减退を來をせる原因と認むる事項}

本事業發足以來，其の生產か所期通り增强し得なかつた事は，先つ新工場の建設整備が著し

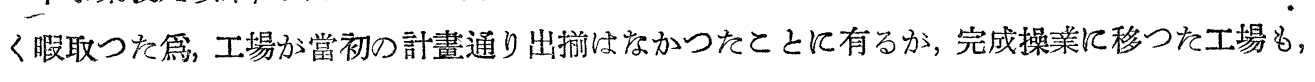
計畫能力を發揮するととが出來なかつね，即ち工場が出來をが所定の生產をなし得なかつた震

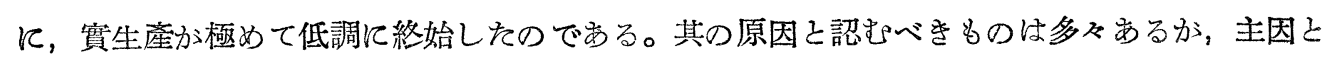
認むや゙きものを列擧して見るき，第一には原林石炭の不足と炭質の低下とである。政府配炭の 主務者も夜䯘燃料增產の重要性は相當徹定的に了解されて居り, 配炭計畫等に於て人石割當は 常に優位に考へられたのであるが，何せん低乾原料炭々他の瓦斯用炭と競合を來し，根本的に 常に品不足の狀態にあつた。又三他の原料炭の如きも, 他之り適睤炭を供給すれば明らかに其 の操業を改善し，生産增强せしめ得る確信が有り乍ら，之を實行に移し得なかつそのである。 刃宇部の如きけ，低乾に適する良質炭の晶不足の篇，致方なく低資大派炭の大量使用を餘義な くせられれのである。

第二には勞務者の不足であつた。との結果, 工場の整備に終始缺くる處が有り, 能力の咸退 を餘義店くせら，又樺太の如を自家探炭の工場に於ては，炭礦勞務者の不足は出炭の减少之

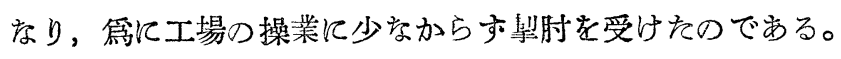

第三には，䒾置機械谸補修の不完全であつそ。之は獨り人石工場のみななず, 大戦中各產業

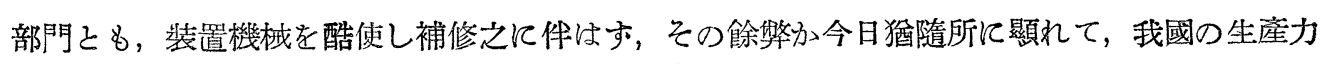
を减退蹉跌せしめ，戰禍つ意想外大なるととを痛感せしめつつある次第であるが，政府として る戰時中は生產力擴充刀輪廓に捉はれて，新工場の建設には惜しけもなく資材を出し，工作を 充當した。特に雨軍と直接の關係ある工場にはとのととが甚たしかつたのであつそか，既存工 場の補修は之を行はすとも能力發揮に差支へなをが如く考へられたものか, 補修資材は極端に

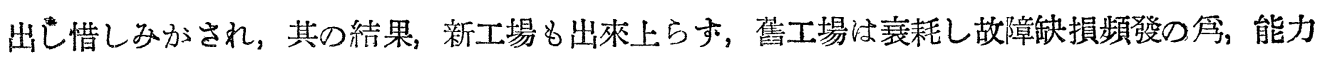

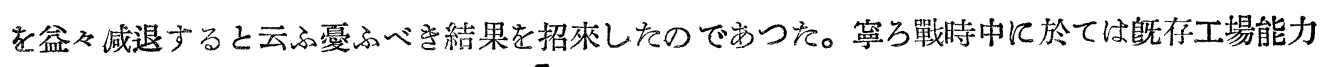
の完全維持を第一義とし，餘力を新工場の建設に向けると云市やり方を致すべきで、斯く致し 
えとすれば，大戰末期に於て我國の生產力はすの樣に減退せしめすに，相掌維持为出來らので

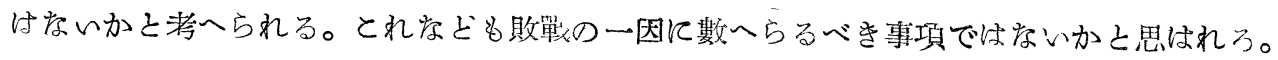

第四に，終戰期に近付いてから生產を急激に减退せしめ最大の原因は，空襲に依る工場の 直接被害と，之に關聯せる輸途力の减退之，頻繁なる作業停止其他に基く作業能率の低下，等 である。敵の空襲目標は，最初に航空機製造閣係の工場に指向せられ，次てで，石油工場，人 石工場, 大都市, 中小都市之指向せられたのは, 衆知の通りであつて, 終践年度をる昭和 20 度に於ける人石の生産は, 前迅の如く實に $45,000 \mathrm{kl}$ 迄低下し, 終戰時には生產か殆ん之杜

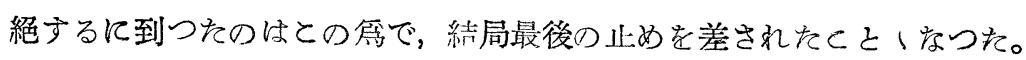

\section{〔III] 戰 災 被 害 $の$ 概 況}

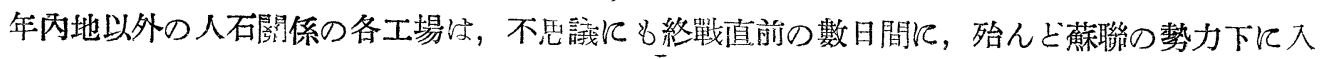
つそのである。この中樺太の內淵內幌の兩工場々，終䟠後も引續き生產を繼續して居る樣了で ある。阿吾地, 吉林, 撫順等は消息不明で, とれ等の地域の他の齐業設備の多く、，蘇聯當局 の言明に依ると，戰利品であるとの見解の下に，殄んど他へ搬出せられれ如く新聞で傳へられ

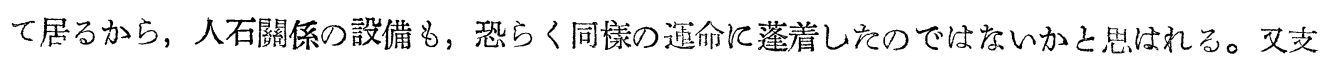

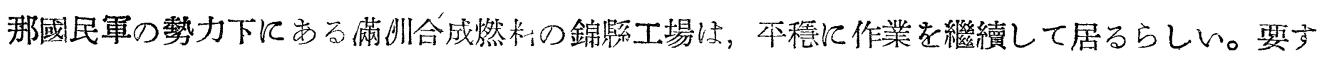
るに，內地以外の諸工場は，其の㥨否如何に係けらす，我國の人造石伷工業としての終止符を

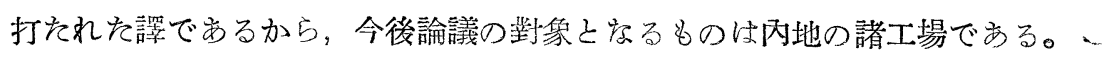

內地の諸工場に就て昭和 20 年度に蒙つを空襲被害の概況を要約すると，北海道に於ては， 日人石留萌工場（閏滑油 $3,000 \mathrm{kl} ，$ エチルベンゾール $2,000 \mathrm{kl}$, 計 $5,000 \mathrm{kl}$ )，龍川工場（合成粗油 15,000 $\mathrm{kl}$, 建設中のノールスタール $10,000 \mathrm{kl}$, 計 $25,000 \mathrm{kl}$ )，日本伷化空知工場（建設中のノールスタール

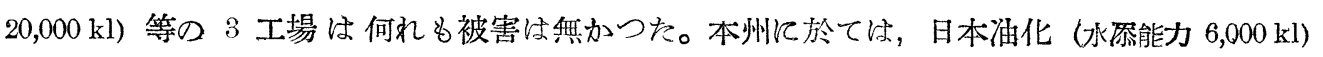
は高壓水添部門を除さ壤缄，日人石尼崎工場（合成粗油 $10,000 \mathrm{kl}$ ) は壊减，帝燃宇部工場（ルル キタール $38,000 \mathrm{kl}$, コッパースッール $10,000 \mathrm{kl}$, 水添能力 $20,000 \mathrm{kl}$ ) は壞缄, 宇部興産 (コッパースタ

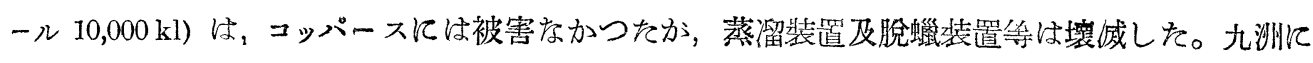
於ては，日産若松工場（タール31,000 kl) はベンヂン蒸溜工場が全㛾したが，其の他は部分的の

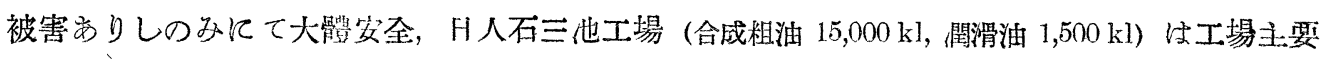

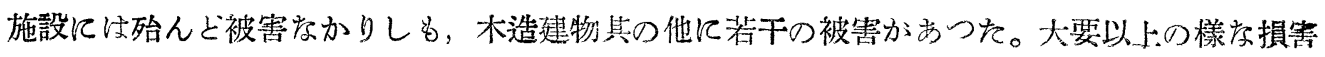
を蒙つたけである。

戦災飞低る人石工場關係の死傷者山，日人石尼崎工場に於て負傷者 17 名, 死者 7 名, 日本 油化川崎工場飞於て負賃者 75 名, 死者 62 名, 合計負傷者 93 名, 死者 69 名であつね。又 製品の損耗绀全工場を通算して $2,276 \mathrm{kl}$ であつた。

\section{[IV〕人造石油事業として今後存續せらるるすの}

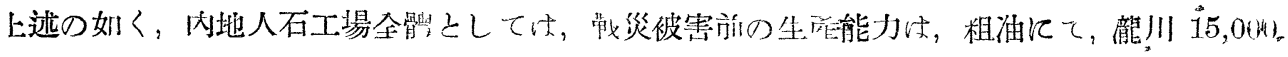

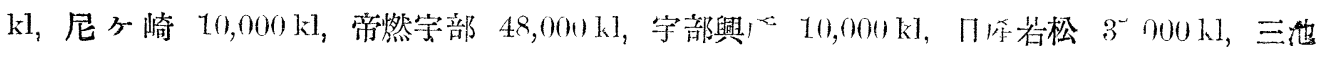

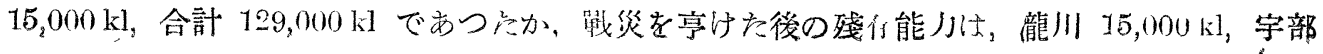


興蓙 $10,000 \mathrm{kl}$ ，日産若松 $31,000 \mathrm{kl}$ ，三他 $15,000 \mathrm{kl}$ 等で合訪 4 工場，能力 $71,000 \mathrm{kl}$ 乙相成

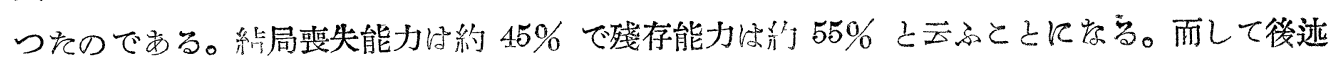
する樣に，との $71,000 \mathrm{kl}$ の能力は令後其儘操業される臎ではなく，龍川の能力の牛分け硫安

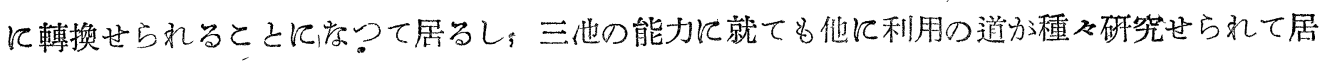

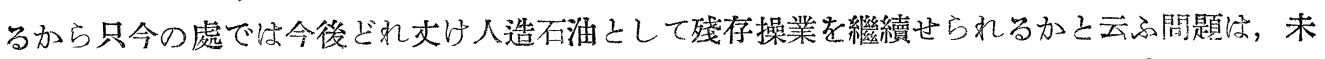

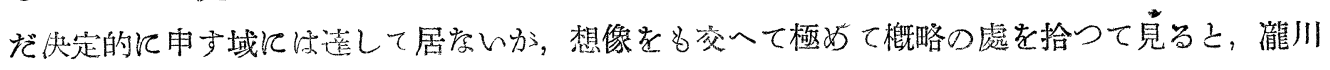
$7,000 \mathrm{kl}$, 本岸 $5,000 \mathrm{kl}$, 日鐵輪西 $3,000 \mathrm{kl}$, 帝然宇部コッパース $15,000 \mathrm{kl}$, 宇部興產 10,000 $\mathrm{kl}$ ， 日産若松 $31,000 \mathrm{kl}$ ，三他 7,000 kl，合計大約 78,000 kl と云ふととになる。とれが現在考 へられる今後の人石事業の操業限界飞對する見透しである。

\section{[V] 被害工場の處理並に轉換方針とその具體案}

昭和 20 年 8 月 15 日今次大戰の終紅考くるや，燃料當局忙郎日關係業者の參集老求め,

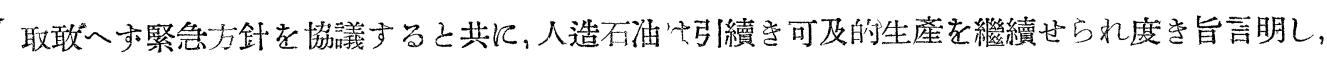
一方人心の安定を圖る之共に，他方戰災被害に依る復舊之其の後の方猃飞就ては，時局の推移 と共に最善案を考究し之を實行に移行ず゙く對處した。次で 9 月中旬關係業者の参加に依る人 造石油事業戰後對策委員會か設りられ，戰苂狀況老調査すると共に，戰後の生產持續及び轉換

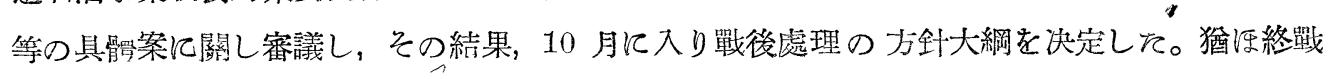
後聯合國側壮，恐らく人石事業に就て全面的停止指令の擧に出つるに非すや，との懸念か我が 方に有つえのであるか，人石の生產は量飞於て問題に宛らす僅少であり，他方外油の輸入は差 當り期待出來をい情勢下に於て，我國の石油需要つ最低限を自給するととか⿱，戰後經營に絕對 て必要であるとの見地に基いた必のであららか, 人石事業の繰業繼續を是認し來つて居るので 市る。

上䢡つ政府に於て策定せられた人石事業戰後處理要絇に袁はれね方針は，「人造石㣙事業は， 假に聯合國がの操業繼續を許容する为人石事業は對内的に運營か困難であり，宜つ意義僅 少原るを以つて，其の主目的老硫安製造て指向し，全面的に之を轉換し，企業の整備再編成を

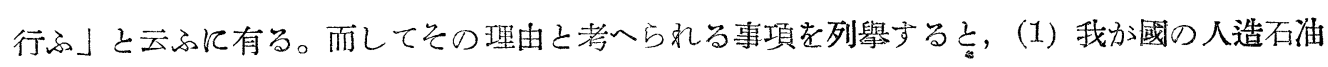

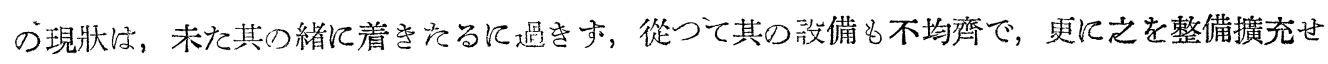

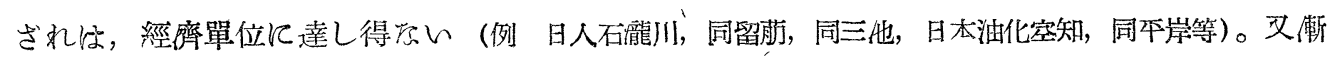
く整備の域に達しれるものも空襲被害の復舊を必要とするを以て，之等工暘の整備には今後佾 巨額の資金と龙大なる資材及び工作力とを要すべ，急變を見つつある我國戰後經㢈下に於て は，之が推進は困難である。

（2）假令整備力出來をとしても，國力の急激なる低下涼原炭，觸媒，其の他の生產諸條件

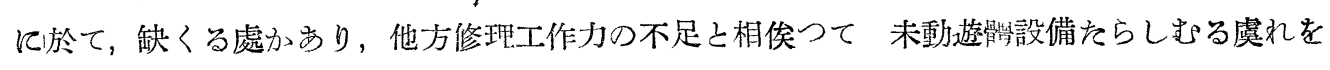
多分に豫期せら机る。

（3）斯業の亭有せる從來の國家保護，即占帝然の金融政策，其他補助金此策，乃至傊格政策 等山，今後之を存續せしむるここ極めて困難で寧ら不可に近い。 
（4）斯業ね，高度國防國家建設の要請に基き發足せる未完成企業で今後外油を主軸とすべき

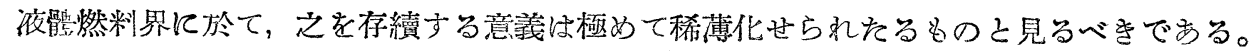

以上の樣な方針及び理由に基き，終㽞後政府及び當事者の間に，人石事業の存續の限度及び

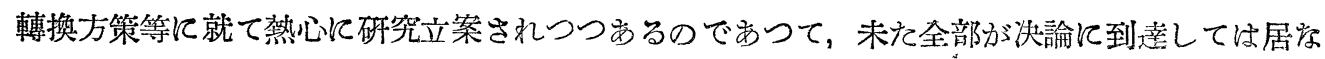
いのであるが，今日迄侄到達して居る處げ大榡次の通りである。

（1）帝國燃料興業株式會社第一事務所 これは宇部の事務所であるがルルギ式低乾裝置は之 を停止し戰災を蒙りをるコッパース式ガス製造望置及びガス猜製装置を復舊し，未完成の合成 裝置，硫酸製造裝置等を急速完成し，全面的飞硫安の製造飞移行せんとするもので，人造石油 としては、コッパース爐の副產タール年 $15,000 \mathrm{kl}$ が得られる豫定である。同所は從前人石を 主とし，併せて硫安 50,000七 の生産を企圖して属を工場であつをか，之を $150,000 t$ 亿擴充 せんとするもので市つて，目下の處昭和 22 年 4 月整備を目標として居る。企業形態 英下の別會社「山陽化學工業株式會社」を創立，4 月初頭發足の豫定であり，帝燃より䠶存設 備評價約 3,000 萬圓を借り受ける之共に，資本金として差當り 2,000 萬圆の出資を仰ぐと之 になつて居る。猶惊帝然直營の大宮研究所は，一酸化炭素變性觸媒，其他の䚡媒製造を目的之 して，別個會社として發足すべく計劃せられつつある。

（2）日人石龍川事業所 當事業所はコバル卜爐を全面的に徵觸媒爐に轉換し，發生可能ガス の約半量を合成して年間約 $7,000 \mathrm{kl}$ の合成情㣙を得，更に之を閏滑油を主體とせる製品に化 せんとするものである。又他の伴量のガスを以つて硫安製造を行ふ篇，新れにアンモニア合成 裝置，硫安製造裝置等を新設し，硫宛年用 10 萬 $\mathrm{t}$ の製造を行々んとする娄のである。而して この硫安轉換の整備は昭和 22 年中に完成を目標として居る。

（3）日人石留荕事業所 既存設備を活用し，魚油よりの硬化㣙及び代用油骫油，スチロール 樹脂，其他化學藥品，醫藥品，食料加工品公の製造に轉換すべく目下隼備を進めつつある。

（4）日人石三他事業所 龍川に於けるコバルト觸媒を全廢して，之を全幅三池に集中すると， 今後 3〜4 年はコバルト觸媒つ持續か可能さ見られて居る。斯くすれは富工皆は、コバルト爐 54 基を以つて年間粗油 $18,200 \mathrm{kl}$ の生産可能乙見られて居るが，目下研究中の案は，龍川之 同樣，生産ガスの牛量を合成に充當し，粗油は之を閏愲油を主體に製品化し，他の牛量のガス は，隣接の東洋高壓へ供給しそ索ら々如何かと云ふのである。何本工場も將來コバルト觸媒の

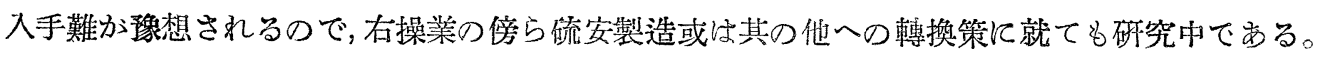

（5）日産夜體燃料若松工場 當工晹以今後も人石事業として最も旗幟鲜明な工場で劣る。郎 ち戰災被害を修復し，既設ルルギ式低乾爐 4 基の操業を繼續し，タール年間 $31,000 \mathrm{kl}$ を生庡

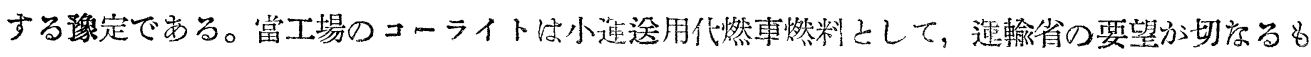
のが有るので之が生產を重蛅視しつつふる。

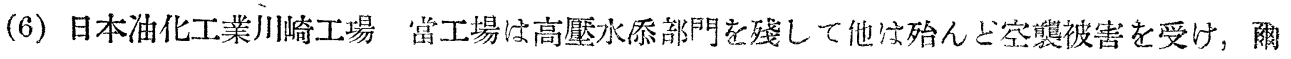
來生産を停止して居る。未た最後案出炔定に到つて居ないか，ノールス爐 15 基及タール蒸溜 裝置を復舅じ,タールの處理を行ひ，ピッチコークス及人造石油の生産を考慮中である。 
（7）日本油化工業空知工場 當工場は當初ノールス爐 180 基整備の.啄定にて建設中であつ たが，終戰に依り工事を停止した。今後は隣接せる當會社の姉妹會社たる化海通炭素工業本岸 王場にて略々完成せるノールス爐 15 基を利用し，新をにタール蒸溜裝置を附加し，石炭年間 7 萬 $\mathrm{t}$ を處理し，各種㒀體然料を生產する方針で隼備を進めつつある。

以上要するに，今後の人石としての殘有工場は，合成法に於て龍川，三他の兩工場之，低乾 に於て本岸，輪西，帝然宇部，宇部興產及び日産若松の 5 工場と，合計 1 工場であるが，て の中，合成法工場の存續に關しては，重大なる命題が殘されて居るのだある。郎ち本年 1 月 16 日以來 3 月 3 日迄の，人石製品買上で價格は，石炭單價 85 圆の基礎に於て合成揮發油 4650 圆，合成 1 號輕㣙 4,300 圓，向 2 號 3,940 圈，之成つて居る。之が更に石炭單價 150

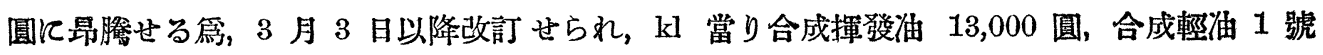
12,000 圆，同 2 號 11,000 圓之飛躍致したのである。尤田國產原油も1月 16 日以降 $\mathrm{kl} 400$ 圆に改訂せられた。當業者の意見に依れば現在の物價水隼に於ては, 之を 2,500 圆程度迄值上 けしなりれは企業の採算困難なる由である。併し作らインフレ下の現壯の生產原價如何は鬼も 角として，現在の樣な狀態を以てしては今後自由産業たらさるを得さる合成法工業の存立は困 難であるとは關係者の意見である。既往に於ける實際工場操業のヒートバランスを見 $C$ も, 著 しく低能率であつたか，獨逸に於ける完成工場の熱効率等は如何なるものであららか。我が國 情では從來の實積でけ今後經席的に存立困難である事實と考へ併せ，茲に今後の合成法工業に 對して投けられをる一大命題が存する次第である。又低乾工昜中，本岸，輪西，帝然字部及び 宇部興產の四社は作業の主目的は他に存して居て, タールは寧ら副生品である。從つて低乾事 業本來の目的に於て今後操業を繼續する工場は, 日産若松 1 工場となる譯であり, 洵に宜ふた るの感があるのである。郎ち人石事業の將來に就き今後眞劍なる研究が行はれ，同事業に對す る正論が勃興するととを希望して熄まさる次第である。 